\title{
MARCAS INSCRITAS NOS MUROS DA ESCOLA: IMAGENS, EDUCAÇÃO E VIDAS PRECÁRIAS
}

\author{
Anderson Ferrari ${ }^{1}$ \\ Roney Polato de Castro ${ }^{2}$
}

FELIPE BASTOS 3

\begin{abstract}
RESUMO: Somos constantemente afetados por diferentes discursos que incitam o preconceito e a violência, presentes, muitas vezes, nas pequenas nuances do cotidiano, mas que também podem emergir explícitos, diretos e escancarados. O presente artigo toma duas pichações - uma de teor racista e outra de teor homofóbico -, feitas nos muros de uma escola pública de uma cidade do interior de Minas Gerais, como ponto de partida para problematizarmos, orientados pelas perspectivas foucaultianas e butlerianas, as imagens formadas nesses muros como potência de jogos de saberpoder e de transformação dos discursos e dos sujeitos.
\end{abstract}

Palavras-chave: Escola. Enquadramento. Heteronormatividade. Pichação. Racismo.

\section{MARKS STAMPED ON SCHOOL WALLS: IMAGES, EDUCATION, AND PRECARIOUS LIVES}

\begin{abstract}
We are constantly affected by different discourses which incite prejudice and violence, often present in the small nuances of everyday life, but which can also come out explicit, direct, and wide-open. The present article takes two graffiti - one with racist and another one homophobic content - made on the walls of a public school in a inland city of Minas Gerais (Brazil) as a starting point for problematizing the images formed on those walls, guided by Foucault and Butler perspectives, as knowledge-power games potency and as discourses and subjects transformation.
\end{abstract}

Keywords: School. Framing. Heteronormativity. Graffiti. Racism.

\section{MARCAS INSCRITAS EN LAS PAREDES DE LA ESCUELA: IMÁGENES, EDUCACIÓN Y VIDAS PRECARIAS}

RESUMEN: Estamos constantemente afectados por diferentes discursos que incitan a los prejuicios y la violencia, que a menudo están presentes en los pequeños matices de la vida cotidiana, pero que también pueden surgir de manera explícita,

1.Universidade Federal de Juiz de Fora - Programa de Pós-graduação em Educação - Faculdade de Educação - Juiz de Fora (MG), Brasil. E-mail: aferrari13@globo.com

2.Universidade Federal de Juiz de Fora - Programa de Pós-graduação em Educação - Faculdade de Educação - Juiz de Fora (MG), Brasil. E-mail: roneypolato@gmail.com

3.Universidade Federal de Juiz de Fora - Colégio de Aplicação João XXIII - Departamento de Ciências Naturais - Juiz de Fora (MG), Brasil. E-mail: felipe.bastos@uff.edu.br

Editora de Seção: Theresa Adrião 
directa y abierta. El presente artículo toma dos graffiti - uno de contenido racista y otro de contenido homofóbico -, hechos en las paredes de una escuela pública en una ciudad en el interior de Minas Gerais (Brasil), como punto de partida para la problematización, guiados por las perspectivas de Foucault y Butler, las imágenes formadas en las paredes como un poder de juegos de conocimientopoder y transformación de discursos y temas.

Palabras-clave: Escuela. Encuadramento. Heteronormatividad. Graffiti. Racismo.

\section{Introdução}

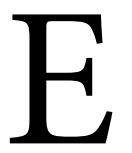

ste artigo foi construído a partir de duas provocações. A primeira veio à tona no interior do grupo de estudos e pesquisas de que fazemos parte, vinculado a uma universidade pública federal, com foco nas questões de gênero, sexualidade e educação. Tal provocação se deu, mais especificamente, a partir da discussão das obras de Michel Foucault e Judith Butler, especialmente aquelas destinadas a problematizar as relações de poder, os enquadramentos e as violências na atualidade (FOUCAULT, 2017; BUTLER, 2018, 2019). A segunda provocação foi motivada por nossa circulação pela cidade e nossas afetações pelos discursos de violência que estão presentes nos nossos cotidianos, mostrando as nuances do fascismo ${ }^{1}$ diário que nos povoam. O encontro dessas duas provocações nos coloca nos trilhos dos escritos de Michel Foucault no que se refere aos seus compromissos de criar condições para uma vida não fascista como possibilidades de uma arte de viver contrária a todas as formas de fascismo (FOUCAULT, 1977).

Tais provocações serviram de inspiração para recuperarmos e problematizarmos dois eventos ocorridos em uma cidade localizada no interior de Minas Gerais, de modo a analisar os enquadramentos que nos constituem e atuam como organizadores de violências destinadas a determinados grupos posicionados como "outros". Essa análise se centra no campo da educação, entendida como algo que vai além do que ocorre nos rituais escolares formalizados, dizendo respeito, também, aos processos de subjetivação, ou seja, de constituição dos indivíduos em sujeitos, como Foucault (2014) nos convida a pensar. Os processos de subjetivação estão sendo pensados como processos educativos, a partir dos quais vamos nos tornando o que somos, aprendendo e ensinando determinados saberes, atravessados por relações de poder. Esses processos também envolvem as potencialidades de colocar sob suspeita esses saberes e como eles nos constituem, ou seja, de produzir outras formas de pensar, ser e agir, inventando outros modos de existências. Assim, orientados pelas perspectivas foucaultiana e butleriana, elegemos duas situações relacionadas a uma escola pública como fio condutor das nossas análises.

\section{Um Muro, Uma Imagem: O Racismo}

No dia 7 de setembro de 2017, data em que se comemora a Independência do Brasil, a cidade foi surpreendida com uma pichação de conteúdo racista em um muro.

Em nossa cultura, grosso modo, a pichação é classificada e enquadrada como aquela atividade que é feita por sujeitos que depredam o patrimônio público e privado, sendo vista como uma prática transgressora, ou talvez por uma experiência limite do sujeito, que impede de ele ser o mesmo como em outras situações (FERRARI; OLIVEIRA, 2020, p. 13). 
O que nos permite chamar a intervenção de pichação, portanto, foi o fato de não ter sido feita em um muro qualquer. Tratava-se do muro de uma das maiores escolas públicas estaduais da cidade, localizada em um quarteirão inteiro de um bairro residencial de classes média e média alta. O muro escolhido para a manifestação racista, voltado para uma das mais movimentadas e importantes avenidas da cidade, em função de um semáforo, obriga os veículos a pararem ao seu lado, garantindo a visualização da mensagem por um número expressivo de pessoas.

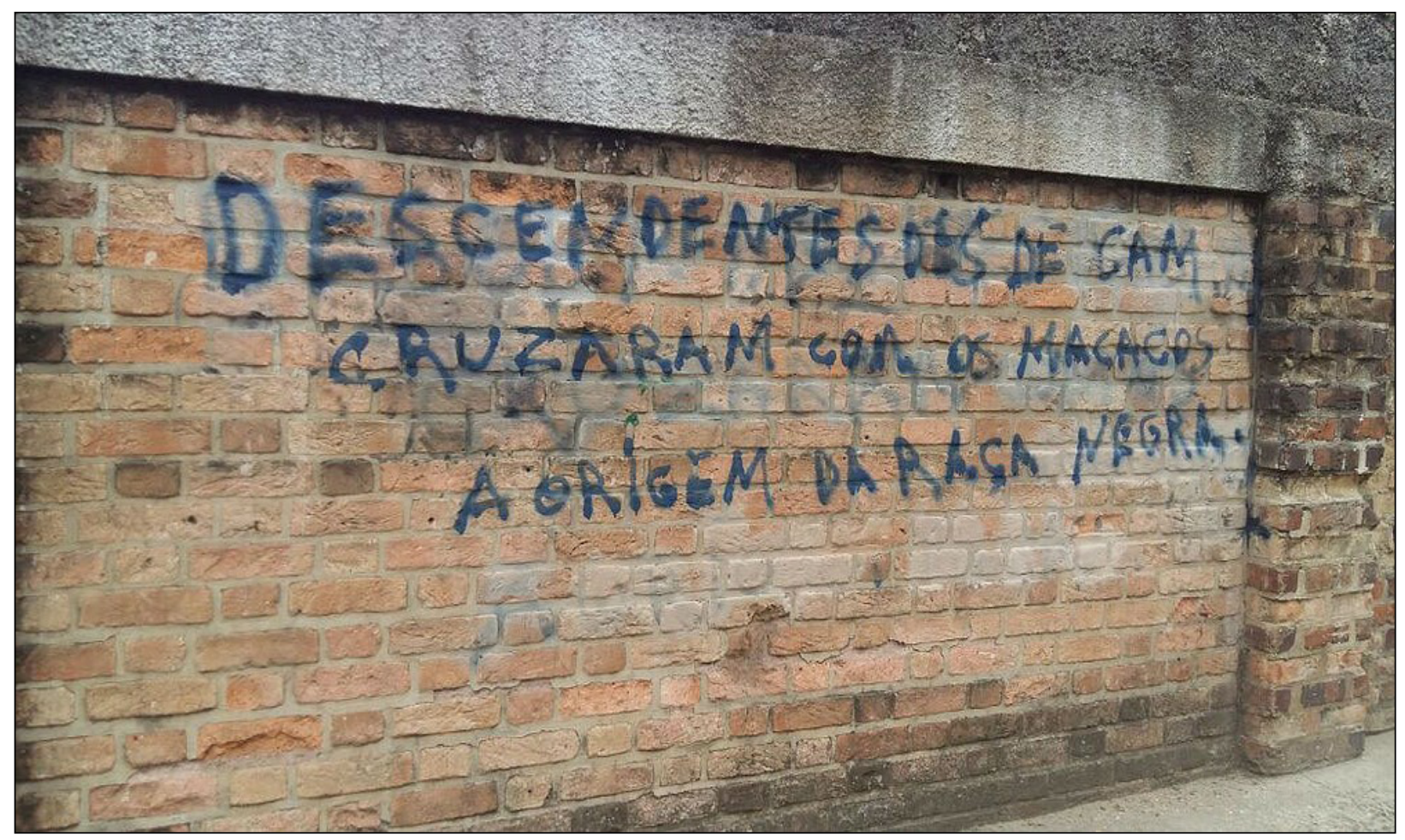

Fonte: Jornal G1 Zona da Mata.

Figura 1. Muro da escola com pichação racista

Ao ser pichado, o que antes era um muro qualquer, transformou-se em um muro com uma mensagem, um enunciado que desempenha função discursiva, adquirindo outro significado. A frase no muro inscreve efeitos nos sujeitos e na cidade a partir de sua materialidade, o que motivou reportagens tanto nos jornais quanto na televisão locais, que inventaram o muro como imagem, extrapolando o que poderia ser visto apenas como uma frase e divulgando e ampliando sua expressão para além desse espaço. Podemos pensar que essa pichação/enunciação só se torna uma reportagem porque acionou um discurso racista que, por sua vez, gerou indignação, resistência e necessidade de reação. Esse efeito da frase nos conduz a duas dimensões. Primeiro, ao caráter positivo dos discursos, como problematiza Foucault (2005): não se trata de um mero conjunto de signos, mas de algo que produz efetivamente aquilo de que fala. Nesse sentido, o enunciado aciona tanto efeitos de reforço do discurso racista, se tomarmos sua função produtiva como efeito educativo de manutenção de um pensamento racista, quanto movimentos de resistência, o que implica pensar que os discursos são ativamente disputados, portanto, histórica e socialmente constituídos. Uma segunda dimensão diz respeito à transformação da pichação/enunciação em imagem, quando se torna uma função de visualidade, podendo ser carregada e reconduzida a outros lugares, a outros sujeitos, ativando os efeitos anteriormente indicados (manutenção e resistências ao discurso racista). Isso é especialmente importante ao considerarmos as preocupações dos jornais e mídias televisivas locais em destacar e transpor a pichação/ enunciação para seus meios, articulando algo próprio desses dispositivos. Assim, a mensagem passa a 
circular para além do muro e do quarteirão, ligando-se a outros enunciados e a outras imagens. Articular a frase, sua função discursiva e seus efeitos imagéticos é uma forma de desviarmos o olhar da imagem para os outros componentes que organizam a cena, apreendendo-os nas suas relações, para novamente voltarmos o olhar para a frase e o muro como imagem. Há, portanto, um processo híbrido, em que frase e imagem compõem uma função de visibilidade, ligando-se a outros enunciados e imagens que tratam de regimes de saber, poder e verdade racistas. São esses movimentos que vamos realizar no presente texto, operando com a problematização foucaultiana dos discursos para colocar em discussão o que pensamos, dizemos e fazemos em determinados local e tempo. Acontecimento discursivo, para Foucault $(2002,2005)$, consiste em acontecimentos históricos. O enunciado que materializa no muro o discurso racista diz respeito a um tempo de longíssima duração, que se renova com outras tonalidades, perdendo a vergonha, o que, em uma sociedade imagética como a atual, toma de assalto os espaços públicos, inclusive um muro de escola.

O muro, que antes pouco informava, foi utilizado como uma tela em branco, um espaço em que foi possível passar alguma informação e disparar a produção de sentidos. Escrita em letras maiúsculas, a pichação dizia: "DESCENDENTES DE CAM CRUZARAM COM OS MACACOS. A ORIGEM DA RAÇA NEGRA”. Essa frase é construída reivindicando um saber, uma posição de agressão, mais do que simplesmente informação, em torno de uma suposta "origem da raça negra". Ao ser utilizado como tela para expressão de uma manifestação racista, o muro adquire novo sentido, podendo despertar, em quem vê, sentimentos diversos: revolta, preocupação, raiva, indignação, mas também indiferença e concordância.

Desse modo, conforme o semáforo libera a passagem dos veículos ou quando o(a) pedestre atravessa para o outro lado da avenida, as pessoas seguem afetadas, de alguma forma, pela leitura e a produção de sentido a partir do enunciado contido no muro. A frase pichada no muro também nos leva a perceber esse espaço que antes passava despercebido. Por argumentar sobre a origem da raça negra, essa frase convida a que nos posicionemos, de maneira que levamos o muro conosco, como imagem que passa a nos constituir.

Assim, trata-se de uma frase pichada por uma pessoa que remete a uma discursividade acerca das relações étnico-raciais no Brasil e se torna imagem, passando a circular e a ser destinada a outras pessoas, o que nos leva a pensar no sentido de imagem como produção e processo educativos, a qual aciona a educação do olhar e produz sujeitos. Isso significa assumir a imagem como dispositivo enunciativo, que diz respeito às práticas atuantes como ferramenta na constituição dos sujeitos (DREYFUS; RABINOW, 1995). Portanto, quando nos referimos a imagem, estamos querendo afirmar que a função discursiva se potencializa com a transposição e a movimentação da frase como pichação; ou seja, há, entre a frase e a imagem-muro, complexas conexões em torno de sua função, que faz funcionar certa discursividade, produzindo efeitos na vida social. São essas articulações e seus possíveis efeitos que queremos problematizar.

As imagens, em seus diferentes e diversos meios de produção, caracterizam nossa sociedade atual. Vamos aprendendo a viver com as imagens e a produzi-las e, como somos invadidos por elas, parece que nos damos o direito de produzi-las em espaços públicos, que também invadem outros sujeitos, sem pedir permissão. Com isso, queremos dizer que esse processo de olhar, produzir imagens e passar informações nos expõe e nos ensina formas de pensar, de ser e de estar no mundo. Vamos produzindo a nós mesmos e aos outros. Segundo Joly (1996), a imagem só existe associada a significados; ou seja, para que algo seja considerado imagem, há a necessidade da construção de significados, o que só é possível a partir de uma produção que envolva, minimamente, dois sujeitos: o que produz a imagem e o que visualiza.

Compreendemos que ela [a imagem] indica algo que, embora nem sempre remeta ao visível, toma alguns traços emprestados do visual e, de qualquer modo, depende da produção de um sujeito: imaginária ou concreta, a imagem passa por alguém que a produz ou reconhece (JOLY, 1996, p. 13). 
A imagem, como uma expressão de arte, é uma prática social e culturalmente instituída, que, como argumenta Martins (2010), gera significados a partir de sua circulação pública. Esse aspecto nos interessa para pensar a pichação e, portanto, a transformação de uma frase racista em imagem - que expressa uma discursividade no muro de uma escola -, bem como os impactos na sua percepção pelos sujeitos, inserindo-se em conexões rizomáticas potencialmente abertas para uma diversidade de interpretações e aprendizagens. Além disso, as imagens também remetem à memória coletiva, cujos significados dependem do contexto, da situação e das relações entre imagem e sujeito; ou seja, os sujeitos interagem em espaços de lacunas, brechas, intersecções (MARTINS, 2010).

Considerando a definição de imagem como implicada em processos de significação e, por conseguinte, de subjetivação, queremos tomar como foco de análise o muro como espaço de veiculação de saberes e discursos transformados em imagem e associá-lo à problematização de Butler (2018) sobre as vidas que importam - sujeitos cuja existência é “aceitável” - e as vidas abjetas, de sujeitos abjetos, que ainda não são considerados sujeitos e se formam para além do domínio do sujeito (BUTLER, 2019). Assim, a discursividade expressada na pichação trata das pessoas negras como vidas abjetas, que podem ser afrontadas publicamente sem que quem enuncia a frase, tranformando-a em imagem, sofra constrangimentos. Nesse sentido, se estamos falando de construção de significados pelos sujeitos, tanto pelos que produzem quanto pelos que visualizam, podemos argumentar que os efeitos das imagens nos sujeitos não são controláveis. Assim, não há garantia de que o significado pretendido por aquele que produz seja exatamente construído por aquele que visualiza. $\mathrm{O}$ efeito pode ser inverso ao que seu produtor originalmente intencionava.

O sentido de imagem atribuído à pichação no muro também foi reforçado, na medida em que, sendo fotografada pelas pessoas que passavam, a imagem, que acionava um discurso racista, era guardada e compartilhada em redes sociais. Dessa maneira, ultrapassava o enquadramento do muro, tomando outra dimensão, que envolvia toda a cidade, e sendo alvo de reportagens nas mídias impressa e televisiva locais. Esses efeitos da transformação da frase em imagem nos remetem ao contexto em que estamos imersos. Vivemos em uma sociedade imagética, na qual somos atravessados/as por imagens o tempo todo, as quais nos capturam, acionam saberes, convocam posicionamentos e, portanto, constituem-nos. Essas imagens participam da construção dos lugares sociais a partir de enquadramentos das vidas que importam - que são dignas de proteção - e daquelas cuja precariedade é potencializada a partir de políticas e práticas de exclusão, violência e morte, como a pichação que aqui tomamos para análise.

O evento de que estamos falando é resultado dessa sociedade que produz imagem o tempo todo e convoca a acionar os saberes que a constituem. Não por acaso, o muro carrega uma frase que remete à história da constituição da população brasileira, em uma perspectiva racista, como marca histórica dessa sociedade, que, vez ou outra, volta a nos atormentar: "DESCENDENTES DE CAM CRUZARAM COM OS MACACOS. A ORIGEM DA RAÇA NEGRA".

A pichação parece remeter a dois aspectos centrais, que podem ser atribuídos ao racismo. $\mathrm{O}$ primeiro diz respeito à parte da mensagem que se refere aos(às) "descendentes de Cam". Como nos conta Munanga (2003), a primeira origem do racismo deriva de uma parte do mito bíblico ${ }^{2}$ de Noé, que amaldiçoa os descendentes de seu filho Cam, ancestral da raça negra, a ser escravizados pelos descendentes de seus irmãos Jafé, ancestral da raça branca, e Sem, ancestral da raça amarela, de acordo com a classificação religiosa. Tal mito foi utilizado por religiões cristãs europeias para justificar e legitimar o racismo e a escravidão como formas de exploração, opressão e dominação.

O segundo aspecto trata da associação desqualificadora entre pessoas negras e animais, como forma de inferiorizá-las e destituí-las de humanidade. Há que se pensar, porém, se esses são os significados acionados pelas pessoas quando deparam com a visualização imagética do racismo propiciada pela pichação, 
que remete aos significados sociais e históricos utilizados na sua produção. $O$ muro informa que esses significados, elaborados em outros tempos, ainda circulam, reiterando efeitos de subalternização e nutrindo ativamente relações de forças que envolvem a manutenção das assimetrias de poder racistas. $\mathrm{O}$ enunciado, materializado no muro, faz circular um tipo de conhecimento vinculado à religião, aos sujeitos produzidos pelos discursos religiosos, seus entendimentos de divulgação de suas crenças e o convencimento do outro no trabalho de catequização diária, utilizando diferentes espaços.

Todavia, lembramos, a imagem não foi produzida em qualquer muro, o que também potencializa os efeitos discursivos da pichação. Por se tratar do muro de uma escola, a instituição foi rapidamente envolvida no debate, sendo considerada, por vezes, responsável pela imagem - senão por sua produção, pelo menos por sua divulgação, já que tal imagem fora produzida e permanecia no muro. Em certa medida, a escola tomou para si a responsabilidade para com os sentidos que operaram na produção da imagem, principalmente para com os efeitos dela nos sujeitos, reiterando sua ação como instância educativa, a partir do que está no cotidiano. A escola foi provocada a tomar o fato como um importante elemento de formação dos sujeitos e de combate ao sistema racista que nos organiza, não conseguindo fugir da sua vocacão pelo ensino, pela transformação de seus(suas) estudantes e pela ressignificação do senso comum por meio dos saberes reconhecidos como científicos. O muro separava dois universos interdependentes com seus saberes, tendo, de um lado, a escola e, do outro, a cidade. A escola é envolvida e chamada a entrar nessa disputa, que é o conhecimento e seus efeitos nos sujeitos. Foucault (2017) nos ensina que as relações de poder são marcadas por disputas, rejeições e fugas; assim, não há poder - ou enquadramento - sem resistências e, em última análise, sem transgressão como fuga para a liberdade do sujeito. O maior efeito da mensagem presente na pichação foi seu combate, um movimento de enfrentamento e utilização do que estava escrito para demonstrar sua inadequação e retomar a necessidade de enfrentamento do racismo pelo conhecimento.

A imagem pode ou não ter sido produzida por algum(a) estudante da escola, mas, de todo modo, podemos supor que o(a) autor(a) dessa pichação tenha passado por uma escola. Com isso, presume-se que possa ter tido acesso a conteúdos que permitiram acionar um saber sobre a constituição das relações étnicoraciais, o que nos possibilita argumentar sobre o papel das escolas na constituição dos sujeitos.

No caso aqui tomado como foco, a escola rapidamente organizou debates com estudantes e reuniões com docentes para discutirem propostas e formas de conduzir o caso, utilizando o argumento da positividade para construir algo que problematizasse e combatesse essa ação, escapando do sentido original e ressignificando seus efeitos. Uma das ações empreendidas pela escola foi apagar a pichação no muro. No entanto, dois dias depois de ter sido apagada, a mesma frase voltou a ser pichada no mesmo local, o que gerou a convocação de uma ação coletiva de estudantes para construírem ali uma arte em grafite, no sentido de valorizar a cultura e a população negras.

\section{Outra Imagem, Outra Condução: A Heteronormatividade}

Antes de passar às problematizações que envolvem a arte produzida por estudantes da escola para substituir a pichação, vamos nos deter a outro acontecimento. Um ano depois da primeira pichação racista, o muro da mesma escola voltou a ser utilizado como "tela" para uma nova pichação, configurando outra imagem e seu regime de enunciabilidade. Dessa vez, foram atacados os gays, recuperando e reacendendo um posicionamento histórico que enquadra homossexuais na condição de vidas abjetas, que não são passíveis de ser vividas (BUTLER, 2019). Segundo Butler (2019), quando falamos de sujeitos, estamos falando da materialidade dos corpos atravessados por relações de poder e sem a qual é imprescindível considerar o jogo 
de sentidos em que assumir um sexo, um gênero e um corpo permite formar uma rede discursiva/simbólica de inteligibilidade pautada na heterossexualidade, excluindo, assim, outros modos de associações. O enunciado que foi construído no muro da escola segue essa lógica de identificação, valendo-se do ataque injurioso e discriminatório às homossexualidades, ligando-as a Aids e reforçando, assim, o imperativo heterossexual. Em letras maiúsculas, a frase agora diz: "GAYS SÃO NOGENTOS [sic]. A MAIORIA TEM AIDS”.

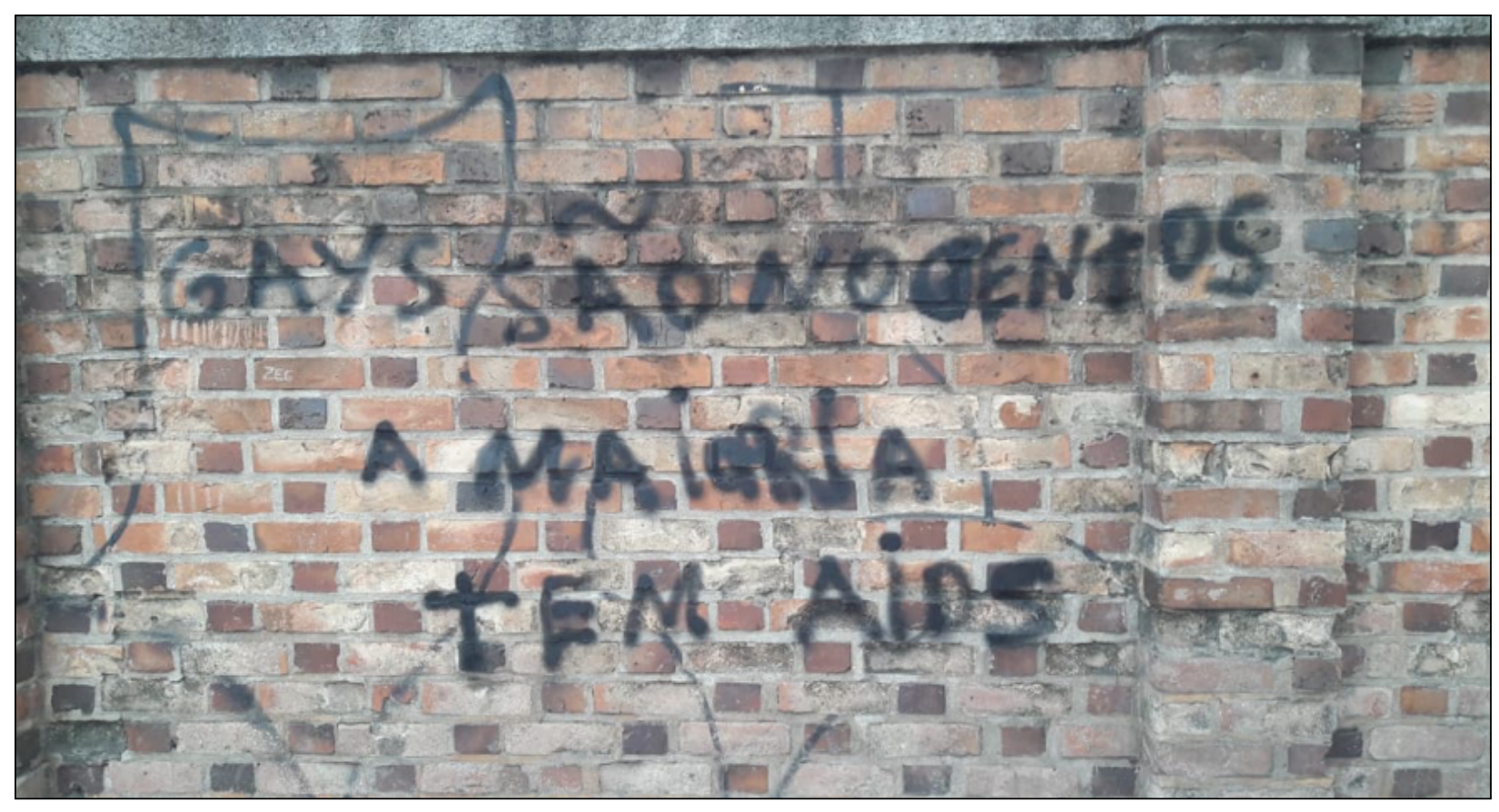

Fonte: Arquivo da escola.

Figura 2. Pichação homofóbica.

Novamente, temos o jogo enunciativo que transforma frase em imagem, ligando-as a certo discurso que funciona como positividade, como forma de reiterar normas sociais e históricas que conferem aos sujeitos seus lugares sociais em função do enquadramento à sexualidade. Assim como o sexo no domínio do dispositivo da sexualidade, os regimes de enunciabilidade não estão diretamente ligados às falas, ditas ou escritas. As visibilidades são relâmpagos, reverberações, cintilações (DELEUZE, 1991), de maneira que as imagens, aquilo que é visível e enunciável, "possam significar trovões que subsistem somente a partir de condições específicas de luminosidade e sonoridade, positivadas tanto pelas relações de força como por outras formas de saber que lhes são correlatas" (MARCELLO, 2004, p. 201). A imagem e a frase, ou seja, o enunciável, parecem só existir em meio a certa aliança entre signos e significados social, histórica e culturalmente construídos - um arranjo específico que, então, atribui-lhes possibilidade de existência.

A imagem, ao materializar um discurso, colocando-o sob condições específicas de luminosidade (MARCELLO, 2004), aciona processos de subjetivação, ao demarcar um sujeito - o gay - como objeto de um saber e vinculá-lo a uma forma abjeta, digna de injúria e escárnio. A partir de práticas como a pichação, nutrem-se relações assimétricas de poder. Assim como no acontecimento anterior, que tinha como foco uma discursividade racista, aqui temos uma imagem homofóbica, que materializa discursos organizadores de uma sociedade heteronormativa, remetendo às disputas históricas em torno dessa significação, sempre retomada e atualizada. Se, na primeira pichação no muro, a preocupação era quanto à suposta origem da uma parcela da população, nessa segunda situação, o interesse estava em definir a condição de existência de outra parcela, absolutizando-a como "nogentos" e lidando com a totalidade como se não houvesse escape: "todos" os gays 
"são nojentos e têm Aids". A sensação de nojo - enjoo, mas também aversão e desgosto -, que é acionada pela imagem, coloca a identidade homossexual como metáfora de uma doença. Também é acionado o discurso médico, datado de meados da década de 1980, que classificava o advento de HIV/Aids, naquele primeiro momento, como "câncer gay"; ou seja, quase um destino manifesto de todos os homossexuais. Esse discurso se mantém vivo pela pichação, que, como imagem, circula, reverbera em outros espaços e educa para a atualização e a utilização desse mesmo discurso como mecanismo de precarização da vida.

Mais uma vez, não se trata de uma imagem em um muro qualquer. Contudo, diferentemente da outra manifestação, de teor racista, essa agressão não teve os mesmos efeitos anteriores na comunidade escolar. Não foi motivo de reunião entre docentes na escola, não foi tomada como oportunidade para discutir sexualidades com os(as) estudantes, não foi geradora de nenhuma reportagem nas mídias locais. Essa falta de reação nos parece resultado da lógica excludente da nossa sociedade, na qual determinados grupos são produzidos como abjetos, isto é, que não podem ser tomados propriamente como "sujeitos" (BUTLER, 2019). Essa sociedade cria as condições de emergência de pichações como aquelas de que estamos tratando, ao mesmo tempo que sustenta o silenciamento e a falta de ressignificação de uma e não de outra.

Se tomamos a ação de violentar grupos sociais marginalizados por meio da exposição de pensamentos racistas e homofóbicos nas duas pichações, podemos considerar que o racismo e a homofobia fazem parte do cotidiano e estão longe de ser superados, tendo em vista uma sociedade menos preconceituosa com quem é posicionado como "outro". Contudo, chamam-nos a atenção as tomadas de decisões diante das práticas adotadas pela escola e pela mídia. Em comparação com as consequências da manifestação racista no muro externo da escola, que fomentou o debate para dentro da própria escola, inclusive dando lugar a uma arte em grafite com mensagem antirracista, o mesmo não ocorreu quando o ataque se direcionou especificamente a gays. A ausência de posicionamento nos remete a um silenciamento heterossexista, que é cotidiano tanto fora quanto dentro da escola.

Nesse sentido, parece não existir muro que separe os dois espaços. Podemos dizer que as escolas, de forma geral, têm mais facilidade de trabalhar com questões raciais e combate ao racismo do que com questões de gênero/sexualidade e combate a machismo, sexismo e LGBTI+fobia. ${ }^{3}$ Essa diferença de tratamento é amparada, inclusive, pela legislação que criminaliza o racismo e por uma legislação educacional que conta com a força da Lei n. 10.639/03, alterada pela Lei n. 11.645/08, a qual obriga o ensino de história e cultura afrobrasileiras e africanas em todas as escolas. Essas leis foram resultado de lutas e organização dos movimentos sociais que entendem a educação como campo de combate ao racismo, o qual deve tomar a história como problematizadora de um passado que se renova no presente. A luta dos grupos LGBTI+ também envolve a possibilidade de criminalizar a LGBTI+fobia nos moldes do racismo, além da tentativa de consolidar o debate das questões de gênero e sexualidade na formação docente e nas escolas.

Como forma de opressão, com base na sexualidade, o heterossexismo confere status de naturalidade à heterossexualidade monogâmica, conjurando tudo aquilo que não se constitui dentro desse regime sexual incluindo identidades dissidentes, como as homossexualidades, mas não se restringindo a elas - como anormal, desviante, abjeto. As atitudes heterossexistas, contudo, não são contingentes e isoladas, mas cotidianamente reiteradas por meio de um sistema de controle e regulação designado pela heteronormatividade, modelo que toma como natural e esperado um determinado tipo de relacionamento binário entre corpos, gêneros e sexos (WARNER, 1993), conferindo privilégios para a heterossexualidade e enquandrando o que foge a ela na condição de anormal. Não por acaso, os gays são vítima da pichação e é necessário defini-los. Quando não há necessidade de pensar a origem de brancos - assim como não há necessidade de pensar a origem das heterossexualidades e o que são elas -, estamos dividindo os sujeitos em naturais e não naturais. 
A heteronormatividade age com base na misoginia e no androcentrismo, de modo a ecoar e estabilizar a superioridade heterossexual masculina - duplo processo segundo o qual um corporifica o outro. Esses dispositivos são acionados por meio de uma matriz heterossexual (BUTLER, 2016), isto é, uma rede de signos e convenções culturais que reiteram a coerência binária dos corpos masculino e feminino ao assumir a estabilidade do sexo e do gênero pelo viés da heterossexualidade compulsória.

São esses símbolos discursivos presentes na pichação que permitem sua própria existência no muro; ou seja, o enunciado só existe na medida em que encontra eco naqueles que passam, olham e carregam consigo a imagem, fazendo-a circular e mantendo-a viva. Para que os corpos sejam compreendidos dentro da malha binária feminino/masculino, é preciso que se tenha um sexo estável e consonante para esse binarismo, mas é preciso, também, que esses corpos, sexos e gêneros operem de modo oposicional. Assim, a construção da masculinidade diante dessa matriz heterossexual se dá também pela rejeição de quaisquer aspectos possíveis de ser associados à feminilidade e, por extensão, à homossexualidade. A pichação que associa os gays a seres "nojentos e com Aids", funciona como expressão dessa rejeição e forma de reiterar outra imagem - o gay -, acionada dentro de uma inteligibilidade fabricada para hierarquizar corpos e sexualidades.

\section{As Imagens e as Vidas Não Passíveis de Ser Vividas}

A vulnerabilidade e a precariedade são marcas constantes de todos os corpos, de modo que não há nenhuma garantia, para qualquer corpo, de persistir vivo e não desaparecer pela morte, seja acidental, seja proposital (BUTLER, 2018). A precariedade é uma característica externa aos próprios desejos do sujeito e não há nenhuma capacidade de controlá-la. Um corpo só pode estar vivo em um mundo que ele próprio não controla e, por isso, está sempre suscetível a perder a própria qualidade de vivo. As duas agressões presentes nas pichações tratam de corpos - trazem para a imagem corpos negros e corpos gays, ao mesmo tempo que evidenciam e reforçam suas vulnerabilidades.

Apesar de a precariedade ser marca compartilhada por qualquer vida, existem diversos fatores que impulsionam a potencialidade de um corpo de se manter vivo e outros fatores que agem de modo contrário, deprimindo tal capacidade, de forma que a precariedade da vida pode ser ampliada ou reduzida. Ainda que todas as vidas sejam potencialmente precárias, os resultados da precariedade - ou as possibilidades de interrupção da vida - não são igualmente compartilhadas, uma vez que são dependentes das relações de poder. Butler (2018, p. 46) chama isso de condição precária; isto é, um conjunto de fatores e circunstâncias induzido em determinados grupos que prejudica suas relações sociais e econômicas, expondo-os a diferentes tipos de violações, violências e morte.

Os sentidos de corpo, gênero, sexo e sexualidade podem ser apreendidos como certas "molduras de sujeito", a partir das quais se tecem expectativas que não somos individualmente capazes de controlar. Tais molduras e enquadramentos conferem inteligibilidade, delimitam as fronteiras possíveis e agem para além do próprio sujeito, que é lido no interior desse quadro. Os processos de enquadramento e a formação dessas molduras de sujeito são também constituídos, discursivamente, a partir de enunciados que circulam em diferentes meios, por distintos suportes (textuais, imagéticos etc.). Os enquadramentos também se relacionam às condições de vida e morte, bem como produzem e reproduzem as condições de reconhecimento do que pode e do que não pode ser considerado vida. Butler argumenta que, do mesmo modo como há determinados sujeitos que não são reconhecíveis como sujeitos, há determinadas vidas que nunca serão reconhecidas como vidas. 
Já estou nas mãos de outro quando tento avaliar quem sou. Já estou me opondo a um mundo que nunca escolhi quando exerço a minha agência. Infere-se daí, então, que certos tipos de corpo parecerão mais precariamente do que outros, dependendo de que versões de corpo, ou da morfologia em geral, apoiam ou endossam a ideia da vida humana digna de proteção, amparo, subsistência e luto (2018, p. 85).

Colocar as vidas passíveis de ser vividas em discussão é também pensar as que não são passíveis. Esse debate parece ter organizado a ação em relação às duas pichações no muro da escola, que tratam de um contexto cultural e histórico específico: a relação da sociedade brasileira com os corpos negros e com os corpos gays. Butler (2018) nos convida a olhar para essa relação entre corpos, sujeitos e desejos que são aceitos e aqueles que são vítima de violência, ao chamar atenção para os processos de violência contemporâneos, os quais resultam dos modos culturais de regulação, aqueles que definem quem deve ser violentado e quem é passível de defesa e proteção. Com isso, a autora investiga o enquadramento seletivo e diferenciado da violência (BUTLER, 2018).

A experiência da vida somente ocorre em meio social e compartilhado com outras vidas, cada qual carregando uma condição precária que é sua, não porque está inscrita anteriormente ao sujeito, mas porque é constantemente atribuída a ele. Algumas vidas, portanto, não serão consideradas passíveis ao luto.

Em outras palavras, "essa será uma vida que terá sido vivida" é a pressuposição de uma vida cuja perda é passível de luto, o que significa que esta será uma vida que poderá ser considerada vida, e será preservada em virtude dessa consideração. Sem a condição de ser enlutada, não há vida, ou melhor dizendo, há algo que está vivo, mas que é diferente de uma vida. Em seu lugar, "há uma vida que nunca terá sido vivida", que não é preservada por nenhuma consideração, por nenhum testemunho, e que não será enlutada quando perdida (BUTLER, 2018, p. 33).

As duas pichações nos muros da escola nos falam que aqueles corpos-alvo da agressão nunca foram vividos para a pessoa que pichou e que, por isso, não seriam motivo de comoção ou luto. Uma vida que não é passível de luto não precisa ser defendida ou cuidada. Na distribuição desigual das condições precárias, essa é uma vida que pode ser mais atingida pela precariedade e vulnerabilidade do que outras vidas. É nesse sentido que agem os enquadramentos, os quais organizam e diferenciam aqueles que podem ser enlutados, e cujas vidas devem ser preservadas, daqueles para quem o luto nunca foi possibilidade, e cujas vidas podem, portanto, ser eliminadas. Para ser passível de luto, há necessidade de ser identificado na sua condição de humano, o que não acontece quando se atribui a origem dos corpos ao cruzamento com macacos, como é apresentado na primeira pichação citada, ou mesmo quando é atribuído o sentido de nojo para os sujeitos. Para construir a ideia de que negros e gays não importam, as pichações descolaram e deslocaram o sentido de humano desses dois grupos, algo que vai se ensinando e que vamos aprendendo, incorporando, reproduzindo e, assim, sustentando a sociedade como racista e homofóbica. O que as duas pichações demonstram é que somos resultado desses discursos que nos constituem de forma sutil, persistente e eficaz. Não é por acaso que a escola é acionada e convocada a se posicionar, confirmando seu entendimento como espaço de força para a transformação dos sujeitos e suas formas de pensar e agir.

\section{A Escola e sua Função Educativa}

Logo após a primeira pichação no muro da escola, aquela que toma o racismo como motivação e teve repercussão na mídia local, a escola rapidamente se organizou para uma ação de combate e de educação dos 
sujeitos por meio de debate sobre as estruturas do racismo, mesmo porque a mídia cobriu a ação da pichação, agindo como uma denúncia à sociedade e convocando a escola a um posicionamento. Na reportagem de um jornal local, intitulada "Frase racista volta a ser pichada em muro da escola: caso que já havia provocado indignação a pedestres, agora será investigado pela Polícia Civil, que instaurou inquérito para apurar autoria”, a escola é convocada a se posicionar.

Em razão da primeira pichação, a direção do colégio havia afirmado ao jornal que a instituição trabalha temas sobre diversidade e cultura afro-brasileira nas atividades pedagógicas desenvolvidas com os cerca de 1.500 estudantes matriculados do $1^{\circ}$ ano do Ensino Fundamental ao $3^{\circ}$ ano do Ensino Médio. [O vice-diretor da escola] reforçou, nessa quarta, que pretende iniciar uma campanha com objetivo de incentivar a reflexão a respeito do racismo. "Vamos começar um movimento, via escola, junto aos alunos, aos professores e à comunidade sobre o que é essa história do Brasil em relação ao racismo e ao preconceito contra os negros", ressaltou, acrescentando que o fato ocorreu no muro de fora da instituição, mas poderia ser em qualquer muro. "Vamos propor ao colegiado da escola a campanha com o mote: 'E se fosse no seu portão, no seu muro, na sua janela, o que você faria?'. Assim, vamos fazer as pessoas refletirem sobre a questão", vislumbra o vice-diretor (ARAUJO, 2017).

Em sua defesa, a escola volta a afirmar o trabalho realizado com a discussão sobre "diversidade e cultura afro-brasileira", assumindo uma abordagem que parece associar-se com o combate ao racismo e argumentando sobre seu compromisso com a formação dos sujeitos. A entrevista ao jornal parece indicar que a escola está acionando um sentido de educação para além da transmissão de conteúdos, como processo ligado às mudanças sociais que conduzem a um olhar problematizador para a sociedade. Ao tomar esse posicionamento, a escola pode estar investindo em um sentido de vida vivível que reconhece as precariedades produzidas pelo racismo e contribui para seu entendimento como vida passível de proteção.

Tal como Butler (2018), que nos instiga a pensar sobre as obrigações colocadas a partir do reconhecimento da condição precária da vida, as intervenções no muro - tanto a pichação quanto as formas como as mensagens foram apagadas -convidam-nos a questionar que vidas são enlutáveis. As ações diferenciais de intervenção da escola sobre as pichações nos dão pistas a pensar que o reconhecimento da precariedade dessas vidas não é o mesmo. Ao que parece, há menos possibilidade de apreender sobre a condição precária das vidas gays, que deveriam ser consideradas dignas e enlutáveis.

Os tijolos que formam os muros daquela escola dão um tom amarronzado a toda a sua extensão, com exceção de uma faixa de cimento cinza no topo. O tom monótono dessas duas cores neutras ganhou inicialmente destaque pela mensagem das pichações racistas, que chamou a atenção não pelo uso de técnicas e cores, conforme mostrado na Fig. 1, mas pelo enunciado preconceituoso. A escola, que, inicialmente, optou por apagar a mensagem, tomou outra decisão quando a pichação reapareceu, organizando, dessa vez, estudantes para que a segunda agressão fosse coberta com uma arte que englobasse não apenas a frase, mas toda uma parte fragmentada do muro. Em tons quentes e contrastantes com o próprio muro, grafitou-se a figura de uma pessoa negra sorrindo e, em seu cabelo, a frase "aqui tem black" (Fig. 3). Novamente, o que temos é a pontecialização do enunciado, o qual passou a compor uma imagem que circulou por mídias locais e redes sociais, produzindo efeitos de destaque e valorização, distintos daqueles enunciados na pichação.

A atitude da escola nos proporciona alguns elementos de análise. Pensando o muro como de propriedade da instituição, a ação de grafitá-lo nos remete aos modos como vêm sendo encaradas essas distintas intervenções. Ferrari e Oliveira (2020) nos chamam a atenção para a significação bastante distinta 
entre pichação e grafite, os quais se diferenciariam segundo os modos como são praticadas tais intervenções e o valor dado a elas. Nesse sentido, a pichação seria vista como produção mais improvisada e aleatória, podendo ser considerada crime contra o patrimônio público e privado, uma prática transgressora. Já o grafite se produziria a partir de um processo mais elaborado e planejado, dimensionando os signos ao espaço e tendo, portanto, uma estética mais aceitável ou mesmo desejável.

No caso em questão, como nos lembram Ferrari e Oliveira (2020), outro aspecto que pode ser ressaltado diz respeito a como as marcas urbanas, inscritas nos muros, prédios e portões de casas e comércios, são percebidas pelos sujeitos, tornando-se parte dessa paisagem urbana e por vezes tratadas com indiferença, à medida que nos acostumamos a vê-las cotidianamente. A escola parece se valer de tais critérios para lidar com as diferentes imagens produzidas sequencialmente em seu muro, considerando o que as pessoas pensam a respeito dessas imagens, como interagem com elas e que tipos de atitudes são demandadas da escola em cada caso. Contudo, coube, principalmente, à escola aprovar ou desaprovar tais práticas imagéticas, o que implica, como discutiremos, outros valores, cujas marcas se inscrevem a partir das imagens: entre as questões raciais e de sexualidade há distintas posturas.

Tanto a pichação - não autorizada, preconceituosa, anônima e possivelmente criminosa, a depender da interpretação - quanto o grafite - autorizado, proposto pela própria escola, com mensagem afirmativa e autoria claramente atribuída - expressam significados, mas têm objetivos diferentes. Ambas as manifestações expressam processos discursivos educativos, vinculando-se às práticas que subjetivam. O enunciado do grafite é afirmativo, ao remeter à presença das pessoas negras na escola, presença essa, porém, que se mostra diferente naquele muro - não mais sob perspectiva racista, mas sob perspectiva de valorização, reconhecimento como vida digna, vivível, enlutável, cuja precariedade precisa ser pensada.

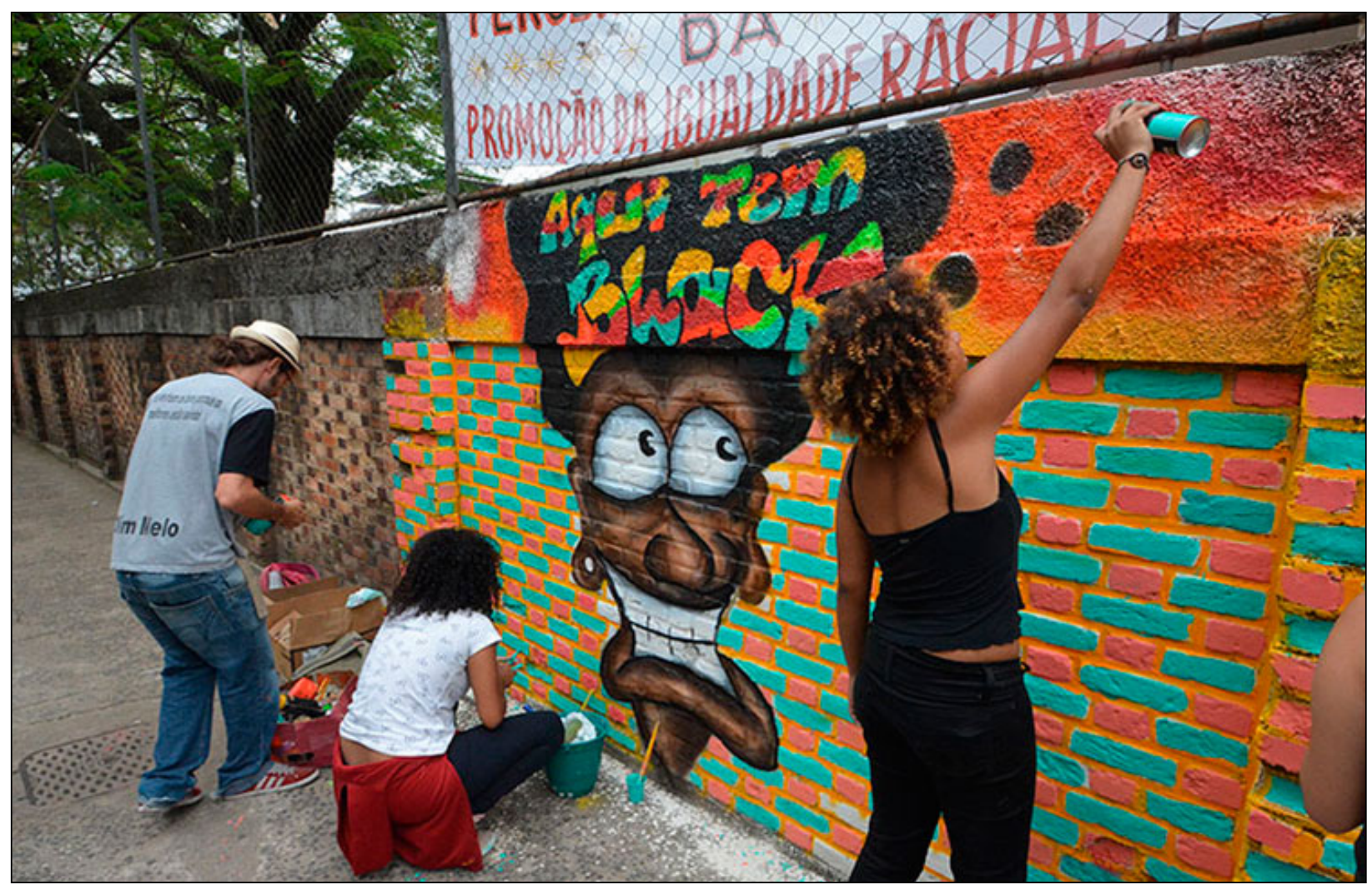

Fonte: Jornal Tribuna de Minas.

Figura 3. Grafite que cobriu frase racista. 
O grafite e o discurso racial que ele materializa no muro fazem um apelo de respeito à diversidade por meio da marcação da existência da pessoa negra na escola. Há, nesse caso, uma discursividade que tende a homogeneizar e apaziguar os embates e dissensos que envolvem as construções das diferenças, a partir da retórica da diversidade e do respeito como posição política contrária às desigualdades. Contudo, cabe questionar sobre qual diversidade se fala. O que ela procura englobar e o que deixa de fora? Em uma leitura das desigualdades de condições precárias que agem em função de determinados enquadramentos, podemos pensar que a decisão da escola tem relação com a ompreensão de que as vidas negras são passíveis de luto e, por isso, devem ser preservadas. O uso de cores e a imagem do rapaz sorrindo e afirmando ter "black" ali explicitam o posicionamento de rejeição às frases racistas anteriores. Quem agora passa por ali é convidado/a a apreender as vidas negras para si não mais como descartáveis, mas como aquelas que merecem a dignidade de ser mantidas e preservadas como vidas a ser vividas.

O mesmo reconhecimento, contudo, não se deu quando o alvo da agressão foram os gays. Sua pichação foi apagada, mas nada tomou seu lugar. Os gays não foram convidados pela escola para produzir um grafite no muro que valorizasse as homossexualidades. Quem passa por aquela parte da escola não é mais convidado a pensar sobre a relevância de uma vida que merece ser vivida. O custo da heteronormatividade em nossa sociedade se reflete na ausência de um belo grafite com os dizeres "aqui tem gay" sobre a pichação. Mais do que isso, podemos pensar se um grafite com tal afirmação seria possível em uma escola. As práticas sociais imagéticas funcionam a partir de jogos discursivos de visibilidade e invisibilidade, baseados em perspectivas históricas de sujeitos enquadrados e normatizados à ordem social vigente.

Nesse sentido, cabe problematizar tais práticas imagéticas como estreitamente ligadas a percursos históricos de saberes e relações de poder, os quais investem para construir as fronteiras desse sujeito enquadrado. Admitir e desejar que haja pessoas negras na escola e em outros espaços sociais, afirmando sua existência digna de preocupação, diz respeito a um percurso histórico de lutas em torno da significação racial, a qual ainda permanece como experiência disputada e tensionada por movimentos sociais, ativismos, instituições acadêmicas e outras instâncias. O que hoje denominamos movimento LGBTI+ também está organizado e tem pautas de reivindicação claras, que incluem a educação e a ação em escolas. Esse é um movimento iniciado no final da década de 1970 como parte da redemocratização brasileira e que se mantém ainda hoje com duas grandes questões: desconstruir as imagens negativas da comunidade LGBTI+ e, ao mesmo tempo, construir imagens mais positivas. A questão parece ser, portanto, a relação desses dois movimentos com a sociedade. Também admitimos e desejamos os gays nas escolas? Que tipo de gays são desejados nas escolas? O percurso histórico que constrói a experiência da homossexualidade permanece estreitamente vinculado a saberes morais, religiosos e médicos que insistem em afirmar sua marginalidade e instituir práticas sociais de hierarquização e subalternização, em uma disputa acirrada entre movimentos sociais, instituições acadêmicas, projetos políticos e religiosos.

O que estamos problematizando é o investimento diferencial entre raça e sexualidade na definição dos sujeitos cuja precariedade não é somente reconhecida, mas digna de proteção. No caso das escolas, a incorporação de uma perspectiva heteronormativa orienta currículos, práticas pedagógicas e relações intersubjetivas, contribuindo para manter o status de naturalidade e normalidade da heterossexualidade. Faz parte desse processo a manutenção das experiências dissidentes, não no lugar de afirmação e reconhecimento, como no caso do grafite que exaltava a presença do "black", mas como fantasmas que rondam os corredores e, por vezes, insistem em aparecer como marcas nos corpos, nas carteiras, nas paredes, nos banheiros e nos muros. Os ideais heteronormativos têm na escola um dos espaços de incisiva e sutil afirmação. Podemos nos perguntar que imagens de gays circulam pelas escolas e que tipo de investimento se faz em um debate problematizador sobre os percursos históricos dos saberes que constroem essas imagens. Nesse sentido, voltamos a nos questionar: um grafite com a frase "aqui tem gay" seria possível em uma escola? 
Uma das possibilidades de pensar tal questão é remetê-la aos contextos social, cultural e político da contemporaneidade, contextos esses de intensa perseguição ao debate sobre sexualidades e relações de gênero nas escolas. Assim, embora as homossexualidades estejam nas escolas - como conhecimento, ainda que silenciado; como classificação, quando no jogo das sexualidades alguém recebe o "rótulo" de gay ou lésbica; como experiência marginal, já que a sexualidade é parte do que somos, portanto, algo que não pode ser deixado do lado de fora quando entramos na escola -, os espaços de debate legitimados têm sido sistematicamente desencorajados e perseguidos. A escola, ao optar por colocar em ação quaisquer abordagens que envolvam esse debate - e isso incluiria um grafite que trouxesse o "ser gay" como algo positivo -, pode sofrer a acusação de ser "doutrinadora” e de promover sexualidades dissidentes em detrimento do que é considerado natural e desejável - a heterossexualidade. Mesmo com um significativo acúmulo de lutas por direitos e conquistas históricas para gays, lésbicas e outros sujeitos de sexualidades não heterossexuais e com expressiva produção de conhecimento que problematiza os percursos históricos de construção das normas e suas dissidências, as escolas se veem reféns de uma discursividade que as amedronta, acionando o pânico e o medo de que possam estar realmente promovendo a multiplicidade e proporcionando o reconhecimento de uma precariedade do vivível que precisa ser protegida e acolhida. Aliás, podemos pensar que a própria pichação homofóbica e outras práticas injuriosas, discriminatórias e violentas sejam respostas a tais avanços, uma forma de resistir a eles, representando o recrudescimento das políticas fascistas que retomam e reafirmam valores e modos de existência heteronormativos.

Ainda pensando no contexto contemporâneo, à época em que as pichações foram produzidas no muro da escola, o racismo figurava como crime, mas a homofobia não. Isso pode ter legitimado uma abordagem pela escola e uma insistência pela mídia local sobre a necessidade de que fosse feito investimento no combate à primeira pichação e não à segunda. O grafite colorido e afirmativo em resposta à pichação racista é um modo de incluir a escola em uma ordem social que se pauta também no discurso jurídico para visibilizar certos sujeitos e experiências e não outros. Embora ressaltemos que se trata de uma suposição, ela nos liga a um contexto atual de disputas que vinculam a escola ao tenso debate sobre sua função social, debate disputado por diversas instâncias, em um contexto de precarização da educação pública e dos sentidos de democracia, inclusão e diversidade, atrelando-os às perspectivas conservadoras, de manutenção do status quo racista e heteronormativo.

\section{Considerações Finais}

Ao analisar os sentidos de silêncio para além do aspecto positivo e necessário de estratégia comunicativa, Andrade e Câmara se perguntam: "quando o silêncio é o saudável exercício de ouvir os demais e a si mesmo? [...] Quando o silêncio se torna silenciamento, ou seja, a estratégia de fazer calar os demais?” (2015, p. 11). As ações analisadas neste artigo - de quem pichou e da escola - se inserem nesses jogos de poderes entre aqueles que podem e os que não podem falar, sobre quais sujeitos afirmaremos com orgulho que "aqui tem" e quais deixaremos às sombras. Em última análise, sobre quais consideraremos vidas a ser vividas e quais nunca nem serão tomadas como vidas.

Nossas análises se construíram em torno do argumento de que somos resultado de discursos que são atravessados por relações de saber-poder, mas que, sobretudo, podem ser desconstruídos. Apostamos no espaço escolar como esse espaço de tensionamento das forças e dos jogos de saber-poder e de transformação dos discursos e dos sujeitos. Nesse sentido, discutimos tanto as condições de emergência de frases como as que organizaram a pichação quanto a constituição dos sujeitos como esse efeito positivo dos poderes e dos 
saberes. Qual é a necessidade de pichar frases como essas? O que leva uma pessoa a se sentir no direito de colocar em um muro de uma escola um pensamento que distingue e separa sujeitos? Talvez possamos inferir que os sujeitos só existam no exercício consigo mesmos e com os outros, de maneira que nós só existimos na medida em que compartilhamos os mesmos significados com os outros. Expor sua forma de pensar racista e homofóbica no muro da escola é um investimento no outro e em um tipo de sociedade que sustenta a existência de quem pichou.

As duas frases separam pessoas negras de brancas e pessoas homossexuais de heterossexuais, mas, mais do que isso, negam a existência e a humanidade dos primeiros para a manutenção dos segundos. A origem e a absolutização das identidades são tomadas como argumentos para a negação da humanidade. Se isso está presente no senso comum e é retomado na pichação, é importante de ser discutido na escola, visto que essas frases também podem aparecer no interior dela, do outro lado do muro, expressando-se por diferentes formas, comportamentos e práticas que muitas vezes não ficam presentes como na pichação e, por isso, não causam respostas de combate, como ocorreu com a pichação racista. "Aqui tem black", mas aqui também tem gay, aqui também tem gay black, aqui também tem gay black pobre... Enfim, nas escolas, podemos pensar que essa frase positiva de assumir a diversidade pode se reproduzir ao infinito quando passamos a olhar para as agressões que organizam esses espaços, mas também para os movimentos de resistência e luta pelo seu combate e pela construção de uma sociedade mais justa e democrática.

\section{Contribuições dos Autores}

Problematização e Conceitualização: Ferrari A; Castro RP; Bastos F; Metodologia: Ferrari A; Castro RP; Bastos F; Análise: Ferrari A; Castro RP; Bastos F; Redação: Ferrari A; Castro RP; Bastos F.

\section{Notas}

1. Quando utilizamos o termo "fascismo", estamos nos referindo às análises de Michel Foucault, que chamou atenção para uma forma de poder presente desde a Modernidade e sobre a qual deveríamos tomar cuidado. Essa forma de poder não corresponde ao fascismo como regime político/social (o que vigorou na Alemanha e é classificado como ditadura política). Diferente disso, o autor queria se referir ao fascismo que habita em cada um de nós.

2. A passagem bíblica que designa o racismo é descrita por Munanga: "Segundo o nono capitulo da Gênese, o patriarca Noé, depois de conduzir por muito tempo sua arca nas águas do dilúvio, encontrou finalmente um oásis. Estendeu sua tenda para descansar, com seus três filhos. Depois de tomar algumas taças de vinho, ele se deitara numa posição indecente. Cam, ao encontrar seu pai naquela postura, fez, junto aos seus irmãos Jafé e Sem, comentários desrespeitosos sobre o pai. Foi assim que Noé, ao ser informado pelos dois filhos descontentes da risada não lisonjeira de Cam, amaldiçoou este último, dizendo: 'seus filhos serão os últimos a ser escravizados pelos filhos de seus irmãos"' (2003, p. 8).

3. Referência ao conjunto de preconceitos, discriminações e violências dirigido às pessoas lésbicas, gays, bissexuais, trans (travestis, transexuais, transgênero), intersexo e demais identidades e expressões de gênero e sexualidade dissidentes das normas. 


\section{Referências}

ANDRADE, M.; CÂMARA, L. Diferenças silenciadas e diálogos possíveis: a pesquisa em educação como superação de silenciamentos. In: ANDRADE, M. (orgs.). Diferenças silenciadas: pesquisas em educação, preconceitos e discriminações. Rio de Janeiro: 7Letras, 2015. p. 8-28.

ARAUJO, M. Frase racista volta a ser pichada em muro da escola: caso que já havia provocado indignação a pedestres, agora será investigado pela Polícia Civil, que instaurou inquérito para apurar autoria. Tribuna de Minas, Juiz de Fora, 2017. Disponível em: http://tribunademinas.com.br/noticias/cidade/13-09-2017/fraseracista-volta-ser-pichada-em-muro-da-escola.html. Acesso em: 3 jun. 2020.

BUTLER. J. Problemas de gênero: feminismo e subversão da identidade. 11. ed. Rio de Janeiro: Civilização Brasileira, 2016.

BUTLER. J. Quadros de guerra: quando a vida é passível de luto? Rio de Janeiro: Civilização Brasileira, 2018.

BUTLER. J. Corpos que importam: os limites discursivos do "sexo". São Paulo: n-1 edições, 2019.

DELEUZE, G. Foucault. São Paulo: Brasiliense, 1991.

DREYFUS, H.; RABINOW, P. Michel Foucault: uma trajetória filosófica - para além do estruturalismo e da hermenêutica. Rio de Janeiro: Forense Universitária, 1995.

FERRARI, A.; OLIVEIRA, B. Marcas na escola: pichação, grafite e subjetividades no ensino com arte. Educação \& Realidade, Porto Alegre, v. 45, n. 1, p. 1-21, 2020. https://doi.org/10.1590/2175-623688923

FOUCAULT, M. Introdução à vida não fascista. Trad. Wanderson Flor do Nascimento. In: DELEUZE, G. ; GUATTARI, F. Anti-Oedipus: capitalism and schizophrenia. New York: Viking Press, 1977. pp. XI-XIV. Disponível em: http://michel-foucault.weebly.com/uploads/1/3/2/1/13213792/vidanaofascista.pdf. Acesso: 15 jul. 2020.

FOUCAUlT, M. A ordem do discurso. São Paulo: Edições Loyola, 2002.

FOUCAULT, M. A arqueologia do saber. Rio de Janeiro: Forense Universitária, 2005.

FOUCAULT, M. O sujeito e o poder. Ditos e Escritos IX: genealogia da ética, subjetividade e sexualidade. Rio de Janeiro: Forense Universitária, 2014.

FOUCAULT, M. Ditos e escritos V: ética, sexualidade, política. Organização, seleção de textos e revisão técnica Manoel Barros da Motta. 3. ed. Rio de Janeiro: Forense Universitária, 2017.

JOLY, M. Introdução à análise da imagem. São Paulo: Papirus, 1996.

MARCELLO, F. A. O conceito de dispositivo em Foucault: mídia e produção agonística de sujeitos-maternos. Educação \& Realidade, Porto Alegre, v. 29, n. 1, p. 199-213, jan./jun. 2004.

MARTINS, R. Hipervisualização e territorialização: questões da cultura visual. Educação \& Linguagem, São Paulo, v. 13, n. 22, p. 19-31, jul./dez. 2010. https://doi.org/10.15603/2176-1043/el.v13n22p19-31

MUNANGA, K. Uma abordagem conceitual das noções de raça, racismo, identidade e etnia. Palestra proferida no 3o Seminário Nacional Relações Raciais e Educação. Rio de Janeiro, 05 nov. 2003. Disponível 
em: https://www.geledes.org.br/wp-content/uploads/2014/04/Uma-abordagem-conceitual-das-nocoes-deraca-racismo-dentidade-e-etnia.pdf. Acesso em: 2 jul. 2020.

WARNER, M. Introduction: In: WARNER, M. (org.). Fear of a queer planet: queer politics and social theory. Minneapolis; London: University of Minnesota Press, 1993.

\section{Sobre os Autores}

Anderson Ferrari é doutor em Educação pela Universidade Estadual de Campinas (Unicamp) e pósdoutor em Educação e Cultura Visual pela Universidade de Barcelona. Professor da Faculdade de Educação da Universidade Federal de Juiz de Fora (UFJF) e professor permanente do Programa de Pós-graduação em Educação da UFJF (PPGE/UFJF). Coordenador do Grupo de Estudos e Pesquisas em Gênero, Sexualidade, Educação e Diversidade da UFJF (GESED/UFJF).

Roney Polato de Castro é doutor em Educação pela Universidade Federal de Juiz de Fora (UFJF). Professor da Faculdade de Educação da UFJF e professor permanente do Programa de Pós-graduação da UFJF (PPGE/ UFJF). Vice-coordenador do Grupo de Estudos e Pesquisas em Gênero, Sexualidade, Educação e Diversidade da UFJF (GESED/UFJF).

Felipe Bastos é doutor em Educação pela Pontifícia Universidade Católica do Rio de Janeiro (PUC-Rio). Professor do Departamento de Ciências Naturais do Colégio de Aplicação João XXIII/UFJF. Membro do Grupo de Estudos e Pesquisas em Gênero, Sexualidade, Educação e Diversidade da Universidade Federal de Juiz de Fora (GESED/UFJF).

Recebido: 24 jul. 2020

Aceito: 4 mar. 2021 